Article

\title{
Does It Matter Where They Train? Transitions into Higher Education After VET and the Role of Labour Market Segments
}

\author{
Miriam Grønning * and Ines Trede \\ Swiss Federal Institute for Vocational Education and Training, 3052 Zollikofen, Switzerland; \\ E-Mails: miriam.groenning@ehb.swiss (M.G.), ines.trede@ehb.swiss (I.T.) \\ * Corresponding author
}

Submitted: 28 February 2019 | Accepted: 7 June 2019 | Published: 5 September 2019

\begin{abstract}
Due to a higher demand for tertiary education, continued educational achievement has become important for the career development of young people with vocational education and training (VET). In this article, therefore, we examine whether the labour market segment of the training firm influences VET diploma holders' likelihood of entering tertiary education. In Switzerland, companies from a wide range of industries and with different institutional characteristics assume a large part of the responsibility for training. Thus, the training firm's position in the labour market impacts apprentices' education and training. Drawing upon segmentation theories, we argue that structural differences between training firms in different labour market segments result in varying opportunities and incentives for higher education. Our analyses are based on a longitudinal national survey of healthcare apprentices who were trained in the primary healthcare segment (hospitals) or in the secondary healthcare segment (nursing homes). Propensity score matching results show that VET diploma holders who were trained in the primary segment were more likely to enter tertiary education than those who were trained in the secondary segment. This finding implies that the structural conditions in the training firm matter for young workers' careers by affecting further educational achievement.
\end{abstract}

\section{Keywords}

apprenticeship; higher education; labour market; tertiary education; training firms; vocational education and training

\section{Issue}

This article is part of the issue "Types of Education, Achievement and Labour Market Integration over the Life Course", edited by Irene Kriesi (Swiss Federal Institute for Vocational Education and Training, Switzerland) and Juerg Schweri (Swiss Federal Institute for Vocational Education and Training, Switzerland).

(C) 2019 by the authors; licensee Cogitatio (Lisbon, Portugal). This article is licensed under a Creative Commons Attribution 4.0 International License (CC BY).

\section{Introduction}

In light of the increasing complexity of working tasks and a higher demand for tertiary education, the longterm labour market integration and mobility of individuals with an upper-secondary vocational education and training (VET) diploma have been discussed in the social sciences (e.g., Forster \& Bol, 2018; Lavrijsen \& Nicaise, 2017). VET diploma holders, i.e., two-thirds of Swiss school leavers, increasingly face hurdles when entering the labour market because of growing competition from more experienced workers and workers with tertiary ed- ucation (Salvisberg \& Sacchi, 2014). In this context, the role of education system characteristics in labour market integration has received growing attention. In particular, research has shown that the degree of specificity of an education programme increases individuals' chances of finding a (skill-adequate) job upon labour market entry (e.g., Eggenberger, Rinawi, \& Backes-Gellner, 2018; Forster \& Bol, 2018; Menze, 2017; Vogtenhuber, 2014). Furthermore, the importance of the firm has been established by research showing that individuals with highly specific, firm-based VET have higher income upon labour market entry than individuals with school-based training 
(Jonker, van Ophem, \& Hartog, 2006; Müller \& Schweri, 2009) but are less mobile (Müller \& Schweri, 2009). However, further differences in education structures within VET, e.g., the types of training firms and their impact on mid- and long-term labour market outcomes and interrelated educational trajectories, have received little attention.

The vocational education system in Switzerland is highly specific and strongly linked to the labour market. The dual training system combines workplace training with vocational schooling. Approximately $90 \%$ of individuals in upper-secondary VET train in a firm-based apprenticeship programme in one of the approximately 230 training occupations (State Secretariate for Education Research and Innovation [SERI], 2016). Although the training programmes have highly standardised curricula and examinations, there are large differences in the work conditions and training quality between firms within training occupations (Hupka-Brunner \& Kriesi, 2013). We draw upon segmentation theory, which states that firms can be clustered into segments according to structural characteristics, to discuss the differences between training firms and their impact on further career decisions. Apprentices experience a segment-specific work environment during training because they spend a large share of their training time in the firm. This influences their perception of career possibilities within their occupation and subsequent transitions into tertiary education. Therefore, in this article, we ask how the labour market segment of the training firm influences uppersecondary VET degree holders' likelihood of entering tertiary education.

The transition from VET to higher education is highly relevant considering that tertiary education is one of the most important measures for VET-diploma holders to keep up with the increasing skill demand and to secure long-term labour market participation (Gomensoro et al., 2017). For workers with a VET occupation, career opportunities and higher education are strongly linked, as early career progression for this group is often contingent upon occupation-specific tertiary level training (Sacchi, Kriesi, \& Buchmann, 2016). Lifelong learning and permeable education systems have also been stressed as solutions for retaining a competent and up-to-date workforce (European Center for the Development of Vocational Training, 2012). Thus, seen from both an individual and an economic perspective, access to tertiary education for those with a vocational upper-secondary degree is crucial for their long-term labour market chances.

To examine our research question, we use the example of healthcare. This has several advantages. First, the healthcare field is divided into two distinct fields, with structural characteristics similar to the primary and secondary segments discussed in the segmentation literature (acute and long-term care). Second, we have data on a homogenous student group who have the same degree and face the same admissions requirements for a limited number of tertiary education options. Thus, we avoid bias in our estimates due to different requirements or the number of options in different training occupations. Third, the Swiss healthcare sector is characterised by a shortage of nursing staff of all education levels (Mercay, Burla, \& Widmer, 2016). Therefore, it is highly unlikely that transitions into higher education function as a strategy to avoid unemployment and that the results are driven by unemployment risk.

\section{Vocational Education in Swiss Healthcare}

The healthcare assistant apprenticeship is the third-mostchosen training programme in the upper-secondary level in Switzerland (SERI, 2016). This training occupation was established not only to provide skilled care workers in the healthcare field but also as a recruitment pool for tertiary nursing education (Oertle Bürki, 2008). The matching process of young individuals and training firms follows a labour market logic, where the compulsory school leavers have to apply for an apprenticeship placement and be hired at a healthcare institution during the three years of training. Almost half of the apprentices train in nursing homes while around a third train in hospitals; the remainder train in homecare, rehabilitation, or psychiatric institutions (Trede, 2015). Healthcare assistant apprentices spend 3.5 days a week on average in their training firm and 1.5 days in vocational school. Although the practical training in most cases is limited to one firm, the diploma is general in the sense that the curriculum and exam criteria are the same for all apprentices independent of where they train. Furthermore, the healthcare assistant curriculum was designed with a general orientation to facilitate mobility and secure broad applicability across healthcare segments (Oertle Bürki, 2008). This orientation is possible because apprentices acquire basic occupation-specific skills and knowledge in vocational school and inter-company courses in addition to the practical segment-specific training (Wettstein, Schmid, \& Gonon, 2017). Thus, after graduation, healthcare assistant diploma holders are qualified to work in all healthcare segments, undertaking care and nursing tasks supervised by registered nurses.

Formally, after completing their VET, healthcare assistants have the same access rights to higher education regardless of where they trained. The numerous tertiary education options for healthcare assistants within the healthcare field are depicted in Figure 1. These degrees are either acquired at a college for higher education (e.g., activation specialist, expert in surgical technology; ISCED $5 \mathrm{~B})$ or, with the prerequisite of a vocational baccalaureate, at a university of applied science (e.g., physiotherapy, midwife; ISCED 5A; see Figure 1). The most frequently chosen option is nursing studies, which are provided at both educational institutions. Registered nurses can further specialise by finishing an Advanced Federal Diploma or a Master of Science. At the colleges for higher education, dual degrees are the standard. This means 


\begin{tabular}{|c|c|c|c|}
\hline $\begin{array}{l}\text { College of Higher Education } \\
\text { (ISCED 5B) }\end{array}$ & $\begin{array}{l}\text { University of Applied Science } \\
\text { (ISCED 5A) }\end{array}$ & $\begin{array}{l}\text { University } \\
\text { (ISCED 5A) }\end{array}$ & \\
\hline $\begin{array}{l}\text { Advanced Federal Diploma of } \\
\text { Higher Education } \\
\text { Expert in anaesthesia nursing } \\
\text { Expert in emergency care } \\
\text { Expert in intensive care }\end{array}$ & $\begin{array}{l}\text { Master of Science } \\
\text { In nursing } \\
\text { In occupational therapy } \\
\text { In physiotherapy }\end{array}$ & $\begin{array}{l}\text { Master of Science } \\
\text { in nursing }\end{array}$ & \\
\hline$\uparrow$ & $\longrightarrow$ & $\uparrow$ & \\
\hline $\begin{array}{l}\text { Diploma of Higher Education } \\
\text { Activation specialist } \\
\text { Registered nurse } \\
\text { Biomed. analyst } \\
\text { Expert in surgical technology } \\
\text { Registered paramedic } \\
\text { Specialist in med. tech radiology }\end{array}$ & $\begin{array}{l}\text { Bachelor of Science } \\
\text { In nursing } \\
\text { In occupational therapy } \\
\text { In physiotherapy } \\
\text { In med. tech. radiology } \\
\text { In nutrition and dietetics } \\
\text { Midwife }\end{array}$ & Bachelor of Science & \\
\hline \multirow[t]{2}{*}{$\uparrow$} & $\uparrow$ & $\uparrow$ & \\
\hline & $\longrightarrow$ & rsity Aptitude Test & \\
\hline$\longrightarrow$ Federal & Federal Vocational Baccalaureate & & \\
\hline $\begin{array}{l}\text { Vocational Education and Training } \\
\text { Healthcare Assistant, Federal Dipl }\end{array}$ & $\begin{array}{l}\text { ED 3)- } \\
\text { of VET }\end{array}$ & & \\
\hline
\end{tabular}

Figure 1. The Swiss healthcare education system. Source: Adapted from Trede et al. (2017) and Dolder and Grünig (2016). Notes: The figure depicts pathways and occupations common in long-term and acute care in the time period of 2011-2016. Education programmes/occupations in bold pertain to hospitals only. The ISCED 1997 classification is used.

that students are employed by a healthcare institution and alternate between on-the-job training and studies at the college. At universities of applied science, internships in different healthcare institutions are required. Access to study programmes outside the field of healthcare requires additional experience or education.

Regardless of the dual nature of healthcare assistant and nursing education, both occupational profiles are general. This means that the healthcare education systems allow licenced healthcare assistants and registered nurses to work in different healthcare segments independent of where they acquired practical training. However, empirically, licensed healthcare assistants who enter tertiary education seldom have experience from a different training segment than the one in which they trained. Only $11 \%$ of the apprentices in acute and long-term care gather work experience as a healthcare assistant outside their training segment before they enter tertiary education. ${ }^{1}$ Even rarer are healthcare assistants who move from long-term care to hospitals before entering tertiary education (5\%). Those who do not enter tertiary education during their early career move around more frequently. Of this group, $47 \%$ have work experience from different healthcare fields during their first five years on the labour market. It is unlikely that many of these will enter tertiary education later. In the healthcare field, $75 \%$ of the VET diploma holders enter tertiary education within six years after their initial training (Swiss Federal Statistical Office [BFS], 2011).

\section{Labour Market Segmentation}

\subsection{Theories of Labour Market Segmentation}

We apply theories of labour market segmentation to analyse the role of the training firm for transitions into higher education. These theories posit that firms with similar characteristics can be clustered into segments. Although there are disagreements regarding the number of segments (Doeringer \& Piore, 1971; Lutz \& Sengenberger, 1974; Tolbert, Horan, \& Beck, 1980), the contributions point to similar characteristics distinguishing the segments. Segments are identified depending on the wage level, qualification level, distribution of qualifications, contract forms, hierarchical structure, and capital intensity of the firms (Averitt, 1968; Baron \& Bielby, 1984; Piore, 2000; Preisendörfer, 1987; Sengenberger, 1975). In the primary segment, jobs are diverse, and tasks within these jobs are complex. Therefore, these firms have a high demand for highly competent and educated employees, and they are interested in retaining these employees. This is done by offering attractive (open-ended) contracts, internal career opportunities, and wage raises in accordance with seniority (Jacoby,

\footnotetext{
${ }^{1}$ These numbers are based on own calculations using data from a longitudinal study with a representative sample of healthcare assistant apprentices. For more information on the data, see Section 5.1 .
} 
1990; Kalleberg, 2003). Internal career options depend on extensive hierarchical structures and diverse horizontal specialization possibilities or niche-positions within the firms. Particularly in large firms in the primary segment, internal firm ladders are prevalent (Sengenberger, 1975). However, these ladders are often interconnected with education requirements, and formal degrees can give access to specific positions and functions within the same institution. In secondary segments, working tasks require a low education level, and firms mostly have a homogenous workforce that conducts uniform tasks. Because this segment is characterised by less complex tasks as well as a shortage of staff, it comprises a high share of unskilled workers (Buchmann, Sacchi, \& Kriesi, 2002). Training new employees is less time- and cost-intensive, thus, workers are easily substituted. Therefore, possibilities for specialization and further education are scarce, and internal advancement opportunities and wage gains because of seniority are uncommon.

The Swiss labour market is divided into occupationspecific subsegments (Sacchi et al., 2016). Mobility within these occupation-specific subsegments is possible for formally qualified workers with a segment-specific VET diploma (Sacchi et al., 2016). However, based on the segmentation literature, we posit that some of these occupation-specific subsegments, such as health care, are further divided into primary and secondary labour markets, which affect the career opportunities of the former apprentices. Therefore, our key assumption is that characteristics, which are specific for the primary and secondary segments, impact individuals' perceptions of career opportunities and consequent choices to enter higher education.

\subsection{Labour Market Segments in Swiss Healthcare}

The Swiss healthcare system can be divided into two main segments: acute care, i.e., hospitals, and long-term care, i.e., nursing homes. Several of the structural characteristics of these two segments are in line with the description of the primary and secondary segments used in the segmentation literature. First, the acute care segment is characterised by higher financial resources than the long-term segment (Camenzind \& Sturny, 2013). Second, there is a large gap in the average education level of the staff in hospitals and nursing homes. Around $70 \%$ of nursing and care staff in hospitals have a tertiary degree while this is only the case for approximately $30 \%$ in nursing homes (Mercay et al., 2016). Furthermore, hospitals are characterised by a lower share of unskilled workers than nursing homes ( $11 \%$ and $29 \%$, respectively; Mercay et al., 2016). Third, the skill dispersion, i.e., the diversity of occupations, is higher in acute care than in longterm care. The work force in hospitals is comprised of a somewhat different set of occupations with tertiary education requirements than the workforce in nursing homes or other healthcare segments (see Figure 1 in Section 2; the occupations in bold letters are prevalent in hospitals only). Tertiary healthcare occupations such as biomedical analyst or expert in anaesthesia work in hospitals but not in nursing homes. Consequently, nursing homes and hospitals also offer internship opportunities in different occupations. In nursing homes, only a few therapeutic occupations are represented in addition to the nursing staff (Dolder \& Grünig, 2016). In contrast, a wide range of options for specialisation after apprenticeship are situated in the acute care segment. In both segments, some shorter courses without formal degrees can give access to training functions, minor management functions (e.g., day- or shift-supervision), or area specialisation (e.g., wound management). However, they yield low returns compared to a tertiary degree, and there is no further career progression foreseeable for these positions. These (minor) career options are mainly concentrated in the long-term segment (Trede et al., 2017). Fourth, the hierarchical structure in hospitals is more complex than in nursing homes (Mächler, 2014). There is a higher demand for tertiary educated personnel across several levels in hospitals. Furthermore, field specialisations and management positions at different levels are more prevalent than in long-term care. Although career progression is not limited to the firm, internal job ladders (for the tertiary trained) are more common in hospitals than in long-term care because of the larger firm size, higher skill dispersion, and hierarchical structure in hospitals. However, internal advancement often includes being hired by the hospital during studies at colleges of higher education (Mächler, 2014). Fifth, task diversity is higher in acute care than in long-term care. Nursing homes are characterised by stable and routine situations of long duration while hospital situations are more unstable and more frequently non-routine, leading to shorter task sequences and higher task complexity. Last, due to the more complex and demanding tasks, the extensive hierarchy, and higher financial resources, the wages for tertiary educated nursing staff are higher on average, and the wage range is wider in hospitals than in nursing homes (Jung, 2019). The wages of healthcare assistants in the two segments are similar. A tertiary degree can thereby lead to higher wage gains in hospitals than in nursing homes. In sum, acute care resembles the ideal typical primary labour market segment while long-term care is similar to the secondary segment.

Our central assumption is that the training firm segment shapes apprentices' perception and choice of further education through three different mechanisms: information, incentives, and supportive work environment. Because of their diverse work environment, apprentices in the primary segment are likely to have more information about their different tertiary education options, subsequent career possibilities, and corresponding wage gains than apprentices in the secondary segment. Further, apprentices in nursing homes are confronted with less benefits from a tertiary education than their counterparts in hospitals. In nursing homes, there are less education and career possibilities as well as limited wage 
development associated with a tertiary degree. Furthermore, healthcare assistants in nursing homes more frequently make minor career steps that are less time consuming and costly than a tertiary degree (e.g., training functions, shift supervision; (Trede et al., 2017). These career possibilities are less accessible for healthcare assistants in hospitals because they are more often performed by tertiary educated staff in these institutions. In sum, healthcare assistants who were trained in nursing homes have fewer incentives to continue into higher education than healthcare assistants who were trained in hospitals. This assumption is supported by previous research, showing that perceived career opportunities are important for nursing turnover within firms as well as the intention to leave the profession altogether (Hayes et al., 2012; Kankaanranta \& Rissanen, 2008). Additionally, those with high extrinsic motivation and high wage expectations are more likely to express and to realise the intention of entering a tertiary degree (Schweri \& Hartog, 2017; Trede \& Schweri, 2014). Last, because hospitals have a higher demand for tertiary educated nursing staff and use healthcare assistant apprentices as a recruitment pool for jobs requiring tertiary degrees, this work environment is more likely to encourage apprentices to continue into further education or to hire them in the context of a dual study programme. Nursing homes, with less demand for tertiary educated healthcare staff and, thus, fewer training positions for students becoming registered nurses, are less likely to support healthcare assistants through further training. Based on these mechanisms, we hypothesise that VET diploma holders who were trained in hospitals enter tertiary education more often than VET diploma holders who were trained in nursing homes.

\section{Individual Level Determinants of Transitions into Higher Education}

Previous research has shown that the transition into tertiary education after apprenticeship training is highly influenced by individual characteristics. In this section, we first discuss the effect of social origin in particular and how it moderates the effect of the training firm segment. Thereafter, we review other individual level determinants.

We have argued that the training firm segment impacts information about tertiary education options, the incentives to enter such education, and the support to do so. A longstanding tradition within social research emphasises how social origin, i.e., parents' educational background, financial situation, and cultural and social resources, affect transitions into higher education through precisely these mechanisms as well (Boudon, 1974; Esser, 1991; for an overview see Kristen, 1999). In line with these arguments, findings show that parents with higher education have a positive effect on both the intention to enter tertiary education and the actual transition net of individuals' performance (Buchmann, Kriesi,
Koomen, Imdorf, \& Basler, 2016; Denzler, 2011; Schmid \& Gonon, 2016; Trede \& Kriesi, 2016). We argue that because some individuals already receive information and support and have higher incentives to enter tertiary education due to their socioeconomic background (SES), training in a hospital might not add a benefit in this respect. First, through their own education, parents with tertiary degrees are more likely than parents without higher education to know about different higher education options and the benefits thereof and to communicate these to their children. Thus, when school leavers from a high social origin start their apprenticeship, they would already have information on tertiary education options and their benefits. Consequently, training in a hospital would yield less new information than for school leavers with parents without a tertiary degree. Second, individuals with higher SES are more likely to enter tertiary education because their cost-benefit calculation differs from those with lower status (Boudon, 1974; Esser, 1991). For the latter group, maintaining parents' status often requires an upper-secondary degree only. Thus, the benefits of a tertiary education are not as high as for the former group.

Furthermore, those with a lower social background have less financial and cultural resources. Thereby, a tertiary degree represents higher costs and risks (Becker \& Hecken, 2007). They might assess their likelihood of successfully entering and completing a tertiary degree as lower than those with higher SES. Training in the primary segment could partly correct for this backgroundspecific high cost and risk assessments and shed light on the benefits of a tertiary degree. Thus, training in a hospital would influence the incentives to enter higher education for those with low SES while less so for those with a higher SES. Last, practical support in families with low social origin, e.g., to apply for a higher degree or to find an internship, might be limited because parents and their social network have limited experience with higher education. Furthermore, because the benefits of tertiary education are less known to this group and the costs are higher, parents might not encourage their children to choose this path (Becker \& Hecken, 2007). Thus, the support and encouragement in hospitals might be especially relevant for this group. In sum, individuals with a high SES are already motivated to enter higher education because of their social background and to receive support and relevant information through other channels than the training firm. Therefore, the information and support provided in hospitals should be more relevant for individuals with low SES. Thus, we hypothesize that the positive effect of training in a hospital is stronger for those with low SES than for those with high SES.

Further individual level determinants of higher education include intellectual abilities and school achievement. Reading skills or math competencies (Buchmann et al., 2016; Schmid \& Gonon, 2016) as well as higher compulsory school tracks and grades (Trede \& Kriesi, 2016) have a positive effect on the probability of enter- 
ing tertiary education. Men are more likely to enter the tertiary A level than women while the results for the influence of a migration background are mixed (Schmid \& Gonon, 2016; Trede \& Kriesi, 2016). In Switzerland, admission requirements for tertiary education vary between the language regions and cantons. Because of this, healthcare apprentices in the French-speaking cantons have a higher likelihood to enter the tertiary $A$ level than those living in the German-speaking cantons (Kriesi \& Trede, 2018; Trede \& Kriesi, 2016). Furthermore, a gap year or periods of unemployment upon labour market entry can have scarring effects regarding later labour market outcomes (Helbling \& Sacchi, 2014; Sacchi \& Meyer, 2016). In addition, lower compulsory school tracks or gap-year activities can hamper the transition into upper-secondary vocational training (Dustmann, 2004; Helbling \& Sacchi, 2014; Sacchi \& Meyer, 2016).

\section{Data and Methods}

\subsection{Data and Sample}

For our analysis, we exploit a longitudinal survey of healthcare assistant apprentices. The full cohort of healthcare assistant apprentices who finished their apprenticeship training in 2011 was surveyed in vocational school one year before the completion of the training. In the first wave, a high response rate of $95 \%$ was reached $(n=2,089)$. The two subsequent surveys were conducted online one year and five years after the completion of the apprenticeship training with $53 \%$ and $48 \%$ response rates, respectively. Because nearly the full cohort participated in the first survey, we can use inverse probability weighting to account for disproportionate panel attrition (Wooldridge, 2010).

The structure of the data allows us to observe the transitions into higher education within five years after the completion of the apprenticeship training. In the healthcare field, $75 \%$ of the VET diploma holders enter tertiary education within six years after their initial training (BFS, 2011). Thus, we capture the majority of transitions with the time frame used. We restrict the samples to individuals who were 15-18 years of age at the beginning of their apprenticeship and trained either in acute care institutions or in long-term care institutions. ${ }^{2}$ At this age, young people typically start an apprenticeship; thus, it constitutes our main interest. After accounting for missing values, the sample consists of 597 individuals.

\subsection{Propensity Score Matching}

Because apprentices are not randomly assigned to training institutions but go through an application process, a simple comparison of the tertiary education rates in the two institutions would be biased. The selection of apprentices into training institutions is likely to be based on individual characteristics that simultaneously affect their probability of training in the acute care segment (treatment) and of the transition into tertiary education (outcome; also see Section 5.3). To overcome this possible selection bias, we use propensity score matching. This technique matches individuals in the treatment group with similar individuals in the control group (training in longterm care), where similarity is based on estimated treatment probabilities. In a first step, we estimate the propensity score, i.e., the probability of being trained in an acute care institution, using a logit model based on a set of covariates. In a second step, similar individuals in the two groups are identified by using the propensity score. Finally, the average treatment effect is computed as the difference in outcomes between the matched groups.

Propensity score matching offers two main advantages. First, since it is a semi-parametric approach, it reduces the risk of potential misspecification of the relationship between the treatment and expected outcome (Morgan \& Harding, 2006). Second, per the common support condition, it only compares individuals who are actually comparable based on observable characteristics. This condition states that groups of individuals who have the same distribution of observed characteristics except for the treatment are compared. The treatment itself must be conditionally independent of the possibly confounding characteristics (the conditional independence assumption). Thus, a limitation of this method is that we can only account for selection into treatment given the observed variables. Furthermore, the influence of the individual characteristics on the transition into higher education could not be empirically depicted since the matched treatment and control group are similar concerning these characteristics.

\subsection{Outcome, Treatment, and Matching Variables}

Our binary outcome variable is transition into higher education, which takes the value 1 if the individual was enrolled in or had finished tertiary education five years after completing their apprenticeship training and 0 otherwise. In our sample, the share of tertiary educated individuals amounted to $74 \%$, of which $10 \%$ had studied outside of the healthcare field. We defined the treatment and the control group based on the type of training institution. Individuals who trained in an acute care institution (hospital) during their apprenticeship belong to the treatment group while individuals who trained in a longterm care institution (nursing home) belong to the control group.

To estimate the propensity score, we use variables that are likely to simultaneously affect selection into treatment and transition into further education at the

\footnotetext{
${ }^{2}$ We excluded individuals who were trained in psychiatric institutions, rehabilitation, and home care or for whom we had no information on the training institution (19.2\% of the initial sample). These institutions might be classified as belonging either to the primary or secondary segment depending on their tasks and structure.
} 
tertiary level. The variables entering the model either hardly vary over the time period in question, or they pertain to the time before the apprenticeship. Thus, they are independent of the treatment. We focus on variables affecting the likelihood of training in the primary segment because the work conditions and career opportunities in hospitals can attract more able and motivated school leavers with a higher SES. Furthermore, the living area impacts the availability of training locations in the two segments, especially since the apprentices generally live with their parents during the apprenticeship. Thus, external sorting, self-selection mechanisms, and regional constraints can have an impact on the allocation into the training segments.

In detail, individual school performance is proxied by the type of track at lower-secondary school. Compulsory school provides nine years of schooling, and the pupils are divided into lower, middle, and higher requirement tracks around the age of twelve. Individual characteristics were indicated by gender, age at VET entry, and migration background. The migration background variable captures whether the respondent was born outside of Switzerland. Place of residence at the time of training is captured with two variables: cantons and rural living area. Cantons, which collaborate in offering healthcare education, were combined. The dummy for rural living area versus urban living areas, i.e., metropolitan areas and agglomerations, is based on federal urbanisation measures for 2014 (for a detailed description, see Goebel \& Kohler, 2014). SES is captured by three variables. Parents' cultural capital is captured by a dummy indicating whether the respondents' parents have more than five bookshelves at home. The highest level of education of the parents differentiates between compulsory school, upper-secondary VET (including baccalaureate), and tertiary education. The highest professional position of the parents is a categorical variable indicating if both parents are not working (unemployed, homemaker, or pensioner) or if at least one of the parents is working as an employee, is self-employed, or is employed in a management position. We further indicate delayed entry into the apprenticeship because of three months or more of unemployment, participation in a further year of schooling, or completion of an internship-like training programme. Last, we account for the pre-apprenticeship motivation to enter higher education. The respondents were asked to report if 'Healthcare Assistant' was their desired occupation when they started the apprenticeship. We distinguish between those who stated that this was their desired occupation, those who saw it as a step towards another occupation, and those who saw it as their second choice or not at all as their desired occupation.

\subsection{Sub-Group Analysis of Individuals with High and Low SES}

To test whether the effect of treatment differs between those with high and low SES, we estimate the propensity score separately for those with parents with a compulsory or upper-secondary degree and those with parents with a tertiary degree based on the same set of covariates as in the main model. However, due to the lower number of cases in each subgroup, age is included as a continuous variable and canton as a categorical variable with three groups (West \& South, Central \& North, and East). This yields the highest covariate balance in the two sub-samples compared to other specifications. Thereupon, the average treatment effect for each group was computed.

\section{Results}

\subsection{Descriptive Results}

Table 1 shows the sample composition by training firm segment. As expected, individuals who trained in hospitals enter higher education more often than individuals who trained in nursing homes. Five years after training, $81 \%$ of those who trained in hospitals had entered tertiary education while this share amounts to $68 \%$ for those who trained in nursing homes. We can further confirm that individuals who trained in the primary and secondary segments differ significantly regarding several characteristics. Those who did their apprenticeship in nursing homes are older and more often finished the lower compulsory school track than those who trained in hospitals. Regarding SES, we find that those who trained in the primary segment have parents in management positions more often and have unemployed parents less often than those who trained in the secondary segment. The distribution of apprentices in acute and long-term care differs between the cantons. Furthermore, the control group more often delayed their apprenticeship because of a practical year, a tenth school year, or a period of unemployment. Last, the majority of healthcare assistants who trained in long-term care had perceived this as their desired occupation before they started training while their counterparts in acute care had seen the profession as a stepping-stone to a higher degree. However, the treatment and the control group have similar percentages of women, persons with migration backgrounds, and persons living in rural areas. Overall, we find the expected differences between those who trained in hospitals and those who trained in nursing homes.

One of the key advantages of propensity score matching is that we can compare groups of individuals who are comparable in relevant observed characteristics. To make sure this assumption holds, we first exclude healthcare assistants from the analysis whose propensity score does not match the propensity score of anyone in the opposite group, i.e., individuals that fall outside of the common support. Figure 2 shows a large overlap of the propensity score for the two groups. The number of excluded individuals not overlapping is low $(n=24)$. Second, to assess the quality of the sample 
Table 1. Sample composition by training segment.

\begin{tabular}{|c|c|c|c|c|c|c|c|c|}
\hline & \multicolumn{2}{|c|}{ Long-Term Care } & \multicolumn{2}{|c|}{ Acute Care } & \multicolumn{2}{|c|}{ Total } & \multirow[b]{2}{*}{$\%$ Bias } & \multirow[b]{2}{*}{$\%$ Bias Matched } \\
\hline & Mean & SD & Mean & SD & Mean & SD & & \\
\hline Tertiary Education & 0.68 & 0.47 & $0.81^{*}$ & 0.39 & 0.74 & 0.44 & & \\
\hline \multicolumn{9}{|l|}{ Age at VET Entry } \\
\hline 15 years & 0.07 & 0.25 & $0.12 *$ & 0.33 & 0.09 & 0.29 & & \\
\hline 16 years & 0.39 & 0.49 & $0.48 *$ & 0.50 & 0.43 & 0.50 & 17.3 & -10.9 \\
\hline 17 years & 0.35 & 0.48 & 0.31 & 0.46 & 0.33 & 0.47 & -7.9 & 6.7 \\
\hline 18 years & 0.20 & 0.40 & $0.09 *$ & 0.29 & 0.15 & 0.35 & -29.2 & -0.1 \\
\hline Migration Background & 0.09 & 0.28 & 0.06 & 0.23 & 0.07 & 0.26 & -10.4 & 1.3 \\
\hline Female & 0.93 & 0.25 & 0.93 & 0.26 & 0.93 & 0.26 & -1.2 & 2.9 \\
\hline \multicolumn{9}{|l|}{ Compulsory School Track } \\
\hline Lower Level & 0.35 & 0.48 & $0.21 *$ & 0.41 & 0.28 & 0.45 & & \\
\hline Middle Level & 0.60 & 0.49 & $0.70 *$ & 0.46 & 0.65 & 0.48 & 21.6 & -5.4 \\
\hline Higher Level & 0.05 & 0.22 & 0.08 & 0.28 & 0.07 & 0.25 & 13.3 & 3.6 \\
\hline \multicolumn{9}{|l|}{ Parents' Education Level } \\
\hline Compulsory School & 0.06 & 0.23 & 0.03 & 0.17 & 0.04 & 0.20 & & \\
\hline Upper-Secondary Degree & 0.63 & 0.48 & 0.60 & 0.49 & 0.61 & 0.49 & -6.6 & 0.0 \\
\hline Tertiary Degree & 0.32 & 0.47 & 0.38 & 0.48 & 0.35 & 0.48 & 12.2 & 1.4 \\
\hline \multicolumn{9}{|l|}{ Parents' Employment Status } \\
\hline Unemployed/Homemaker/ Pensioner & 0.04 & 0.20 & $0.01 *$ & 0.12 & 0.03 & 0.17 & -16.8 & 7.9 \\
\hline Employed & 0.34 & 0.47 & 0.27 & 0.45 & 0.31 & 0.46 & & \\
\hline Self-employed & 0.25 & 0.43 & 0.23 & 0.42 & 0.24 & 0.43 & -2.6 & -0.4 \\
\hline Management position & 0.37 & 0.48 & $0.48 *$ & 0.50 & 0.43 & 0.49 & 21.8 & -3.7 \\
\hline More than Five Bookshelves & 0.33 & 0.47 & 0.30 & 0.46 & 0.32 & 0.47 & -6.0 & -6.7 \\
\hline Delayed VET-Entry & 0.47 & 0.50 & $0.28 *$ & 0.45 & 0.38 & 0.48 & -39.0 & 5.4 \\
\hline Rural Living Area & 0.44 & 0.50 & 0.39 & 0.49 & 0.41 & 0.49 & -9.5 & -5.9 \\
\hline \multicolumn{9}{|l|}{ Canton } \\
\hline $\mathrm{BE}$ & 0.23 & 0.42 & $0.14^{*}$ & 0.35 & 0.18 & 0.39 & & \\
\hline AG & 0.09 & 0.28 & 0.06 & 0.23 & 0.07 & 0.26 & -12.8 & 7.2 \\
\hline BS & 0.04 & 0.19 & $0.08 *$ & 0.28 & 0.06 & 0.24 & 19.6 & 0.8 \\
\hline FR & 0.03 & 0.17 & 0.02 & 0.14 & 0.03 & 0.16 & -5.1 & -2.1 \\
\hline GR & 0.04 & 0.19 & 0.03 & 0.18 & 0.04 & 0.18 & -1.1 & 0.2 \\
\hline SG & 0.11 & 0.32 & 0.13 & 0.34 & 0.12 & 0.33 & 5.2 & 1.1 \\
\hline $\mathrm{SH}$ & 0.01 & 0.11 & 0.01 & 0.12 & 0.01 & 0.12 & 0.9 & -1.0 \\
\hline so & 0.02 & 0.15 & 0.04 & 0.19 & 0.03 & 0.17 & 8.8 & -4.2 \\
\hline TG & 0.04 & 0.19 & 0.03 & 0.16 & 0.03 & 0.18 & -6.7 & 0.1 \\
\hline $\mathrm{TI}$ & 0.03 & 0.16 & $0.00 *$ & 0.06 & 0.02 & 0.12 & -18.9 & 4.1 \\
\hline GE \& VD & 0.06 & 0.24 & 0.03 & 0.17 & 0.05 & 0.21 & -13.5 & -3.5 \\
\hline VS & 0.05 & 0.22 & 0.02 & 0.14 & 0.04 & 0.18 & -15.2 & 0.8 \\
\hline Central $\mathrm{CH}$ & 0.14 & 0.34 & 0.18 & 0.38 & 0.16 & 0.36 & 11.5 & -4.4 \\
\hline $\mathrm{ZH}$ & 0.12 & 0.33 & $0.22 *$ & 0.42 & 0.17 & 0.38 & 26.2 & 5.4 \\
\hline \multicolumn{9}{|l|}{ Pre-Apprenticeship Motivation } \\
\hline HA was the Desired Profession & 0.70 & 0.46 & $0.47^{*}$ & 0.50 & 0.59 & 0.49 & & \\
\hline HA as a Stepping Stone & 0.25 & 0.43 & $0.50 *$ & 0.50 & 0.37 & 0.48 & 53.1 & 2.0 \\
\hline HA as a Second Choice & 0.05 & 0.22 & 0.03 & 0.16 & 0.04 & 0.20 & -12.7 & -0.8 \\
\hline $\mathrm{N}$ & 306 & & 291 & & 597 & & & \\
\hline Mean Bias & & & & & & & 14.2 & 3.3 \\
\hline
\end{tabular}

Notes: $\mathrm{HA}=$ Healthcare Assistant; ${ }^{*} \mathrm{p}<0.05$.

balance, we tested for differences in means across the two matched groups. The mean bias before matching is $14.2 \%$ while the mean bias amounts to $3.3 \%$ after matching (see Table 1). Concerning the separate matching results for those with high and low SES, the bias is reduced from $25.5 \%$ to $5.4 \%$ for those with tertiary educated parents and from $17.6 \%$ to $3.6 \%$ for those with parents with upper-secondary degrees (results not shown). ${ }^{3}$ These results show that we compare similar individuals based on the observed characteristics.

\footnotetext{
${ }^{3}$ Sub-group results showing the sample composition before and after matching as well as bias reduction are available upon request.
} 


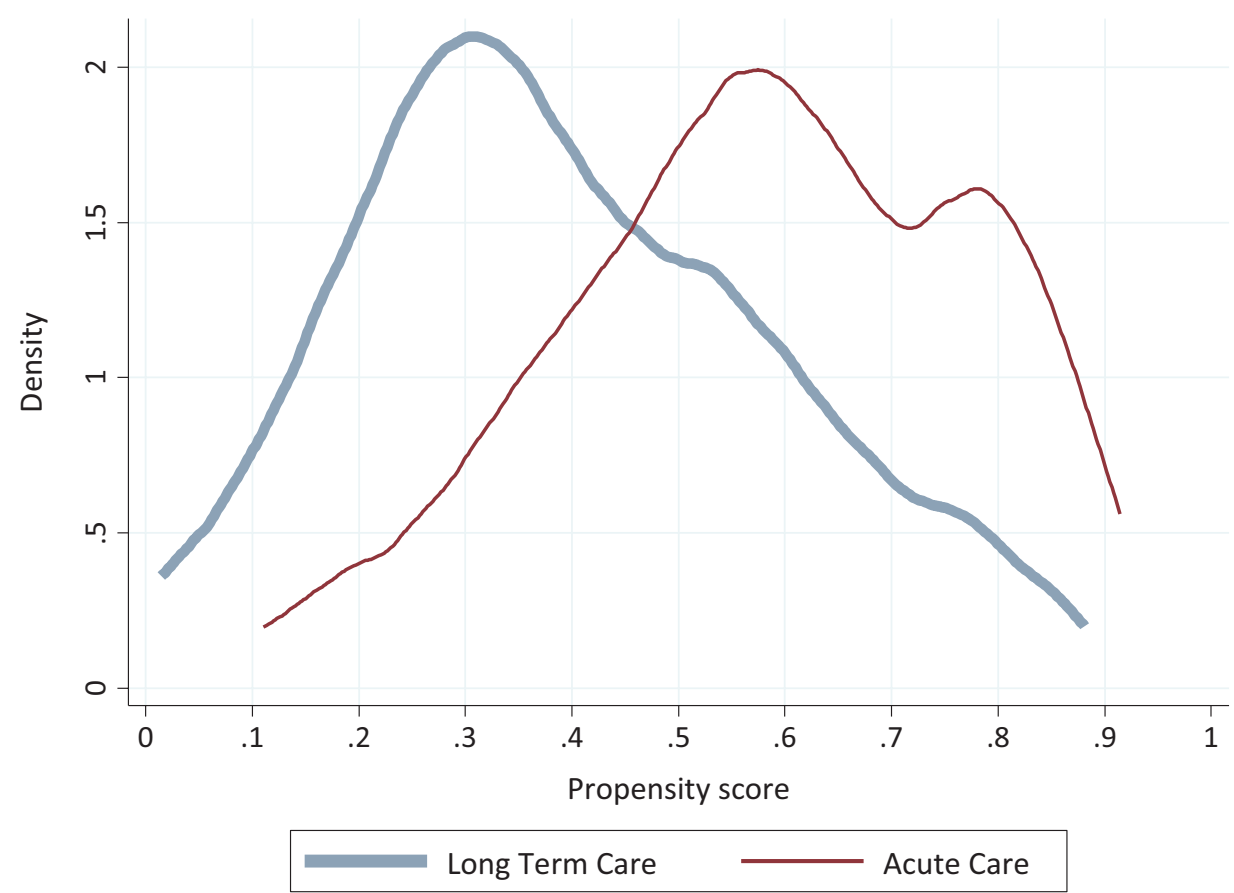

Figure 2. Kernel density plot of the estimated propensity scores, calculated separately for the treatment and control groups.

\subsection{Main Results}

The average treatment effect for the full sample, i.e., the average effect of training in acute care compared to training in long-term care, is shown in Table 2 in the first row. The main results in the first column confirm our hypothesis that the training firm segment impacts transitions to higher education. Those who trained in acute care have a 9.4 percentage point higher probability of entering tertiary education than those who trained in the long-term segment. Thus, the descriptive difference in the transition into higher education rates does not solely arise from the different composition of apprentices in nursing homes and hospitals. A large part of this difference is due to the allocation to the training firm segments. This finding supports our assumption that the extensive career opportunities, higher demand for tertiary degrees, and more favourable wage prospects in hospitals impact the choice of healthcare assistants to enter tertiary education. To assess whether our main results are biased by disproportionate panel attrition, we first include inverse probability weights ${ }^{4}$ and, second, use the larger sample surveyed one year after the apprenticeship. These results are presented in the second and third column in Table 2. The average treatment effect for the full sample, controlling for attrition, only marginally differ from the main results. The average treatment effect varies between 8.3 and $9.4 \%$.

Next, we turn to the estimated average treatment effect for those with parents with no more than an uppersecondary education (second row). In accordance with our second hypothesis, the main results show that training in hospitals is more important for those with low SES than for those with high SES. The positive effect of being trained in acute care for healthcare assistants with parents with compulsory or upper-secondary education is significant at a $10 \%$ level. For these individuals, training in hospitals increases the likelihood of entering tertiary education after VET by $9.2 \%$. The treatment effect for healthcare assistants with parents with low education is similar to the average treatment effect for the full sample (0.094). Thus, it is likely that our overall result for all respondents is driven by the higher number of individuals with parents with no more than an upper-secondary degree in the sample. The analysis, considering attrition, shows stable effects of having parents with low education in both size and significance (the average treatment effect ranges from 0.092 to 0.109 ). It seems that particularly those with low SES can benefit from the structural characteristics of a hospital. If this group had not entered training in a hospital, they likely would have had less incentives to enter higher education, experienced less support, and had less information about their advancement possibilities and the benefits thereof.

Last, the average treatment effect for those with at least one parent with a tertiary education is shown in the third row in Table 2 . The main results show that for individuals with parents with tertiary education, training in a hospital has a small negative and statistically insignificant effect (-0.029). Furthermore, the weighted estimation for this group shows a positive effect of training in the primary segment (0.062). However, this effect is not

\footnotetext{
${ }^{4}$ The inverse probability weights are calculated with a probit model with attrition as the dependent variable and the matching variables as well as the variables used by Trede (2015, p. 176) as the independent variables. The treatment effects are then calculated using the product of the inverse probability weight and the propensity score weight from the main model (DuGoff, Schuler, \& Stuart, 2014).
} 
Table 2. Treatment effects of training in a hospital on the transition into higher education.

\begin{tabular}{|c|c|c|c|c|c|c|c|c|c|c|}
\hline & \multicolumn{4}{|c|}{ Main Results } & \multicolumn{3}{|c|}{ Including Attrition Weights } & \multicolumn{3}{|c|}{$\begin{array}{l}\text { Transition within } \\
\text { One Year after VET }\end{array}$} \\
\hline & $\begin{array}{l}\text { Aver } \\
\text { Treatr } \\
\text { Effect }\end{array}$ & $\begin{array}{l}\text { age } \\
\text { nent } \\
\text { (SE) }\end{array}$ & $\begin{array}{c}\mathrm{N} \\
\text { Treated }\end{array}$ & $\begin{array}{c}\mathrm{N} \\
\text { Control }\end{array}$ & $\begin{array}{l}\text { Average } \\
\text { Treatment } \\
\text { Effect (SE) }\end{array}$ & $\begin{array}{c}\mathrm{N} \\
\text { Treated }\end{array}$ & $\begin{array}{c}\mathrm{N} \\
\text { Control }\end{array}$ & $\begin{array}{l}\text { Average } \\
\text { Treatment } \\
\text { Effect (SE) }\end{array}$ & $\begin{array}{c}\mathrm{N} \\
\text { Treated }\end{array}$ & $\begin{array}{c}\mathrm{N} \\
\text { Control }\end{array}$ \\
\hline Full Sample & $0.094 *$ & $(0.043)$ & 281 & 292 & $0.083 *(0.037)$ & 269 & 281 & $0.094 * \quad(0.039)$ & 397 & 432 \\
\hline \multicolumn{11}{|c|}{ Parents' Education Level } \\
\hline $\begin{array}{l}\text { Secondary } \\
\text { Degree }\end{array}$ & $0.092+$ & $(0.049)$ & 178 & 199 & $0.109 *(0.051)$ & 171 & 194 & $0.097 * * \quad(0.049)$ & 241 & 300 \\
\hline $\begin{array}{l}\text { Tertiary } \\
\text { Degree }\end{array}$ & -0.029 & $(0.066)$ & 107 & 90 & $(0.070)$ & 102 & 88 & $0.106 *$ & 159 & 127 \\
\hline
\end{tabular}

Notes: ${ }^{* *} p<0.01,{ }^{*} p<0.05,+p<0.1$; Epanechnikov Kernel Matching with bootstrapped standard errors in parentheses, each with 200 repetitions. $N$ Treatment and Control: number of matched Individuals in the treatment and control groups.

significant and is still smaller than the effect for those with parents with low education. Last, the analysis with the larger sample surveyed one year after training show similar, positive, and significant effects for both groups (0.106). Thus, overall, the average treatment effect for those with parents with higher education varies somewhat. This could be due to a low number of cases in this group. Another possible explanation could be that the effect of training in a hospital is strong for both groups immediately after the apprenticeship but wears off more quickly for those with more highly educated parents. Although training in a hospital might foster the motivation to enter a tertiary degree for those with less educated parents, they might want to work for some years to be able to finance their higher education and living costs during further studies. For those with parents with higher education, financial barriers should not be as important. Therefore, the motivation boost given by training in hospitals would predominantly lead to direct transitions. Thus, the effect of the training firm segment fades out more quickly for the higher educated. However, because of the inconclusive results, the effect of the training firm segment for individuals with high SES needs further consideration.

\section{Discussion and Conclusion}

In this contribution, we focus on the relationship between the types of education and mid- and long-term labour market outcomes by asking whether the labour market segment of the training firm impacts former apprentices' likelihood to enter tertiary education. We highlight the role of the training firm segment, a hitherto neglected topic in research considering education system characteristics. This research has largely focused on differences between general and vocational education tracks and failed to incorporate the heterogeneity within the VET-system. Further, we draw upon segmentation theory to discuss the heterogeneity and the impact of training institutions and test our hypotheses based on longitudinal data concerning apprentices in the healthcare field.

Our findings show that allocation to training firm segments matters; those who trained in the primary segment have a higher likelihood to enter tertiary education than those who trained in the secondary segment. This result is particularly striking, considering that VET diploma holders formally have the same access to tertiary education independent of their training segment. Nevertheless, the finding supports the assumption that the structural characteristics of the training firm segment, such as financial resources, average education level, skill dispersion, hierarchical structure, task diversity, and wages, can impact how individuals perceive their career opportunities. Furthermore, we find that those with lower SES particularly seem to benefit from training in the primary segment. This could be because training in the primary segment gives access to resources that this group cannot access through their parental home. Thus, training in the primary segment could compensate for initial disadvantages due to lower SES.

Both theoretical and practical implications can be derived from this result. First, dominant theoretical approaches explaining educational transitions have mainly focused on individual determinants like gender (e.g., Griga, Hadjar, \& Becker, 2013), social origin (e.g., Denzler, 2011), migration background (e.g., Trede \& Kriesi, 2016), or expected returns (Schweri \& Hartog, 2017). Our results show that when education programmes are strongly linked to the labour market, labour market characteristics also influence these transitions. We have described a range of structural characteristics in the two labour market segments that impact apprentices' career perceptions through their experience in the training firm. Investigating the distribution of these characteristics across firms and assessing the relative importance of these different characteristics for career decisions would shed more light on the relationship between the meso-level, i.e., firms, and individuals' educational 
choices. This relationship should be relevant not only for apprentices but also for other groups alternating between education and work, e.g., trainees, interns, adult learners, or regular students with part-time jobs.

Second, in the highly stratified Swiss education system, several bottlenecks regulate access to VET, such as entering dual training compared to postponing the training with an additional year of schooling (Sacchi \& Meyer, 2016) or the access to the favoured occupation. These bottlenecks influence individuals' chances and reinforce earlier disadvantages (Hupka-Brunner, Sacchi, \& Stalder, 2010; Protsch \& Solga, 2016). Our results show that access to the primary segments during the apprenticeship can represent a further bottleneck, which may also reinforce disadvantages. In particular, those from lower compulsory school tracks and those with less favourable SES face difficulties entering training in the primary segment. This can, in turn, hamper their access to information about tertiary education and its advantages.

Third, the strong differentiation between the segments during training can hinder career development and lead to drop-outs. This is especially relevant in the healthcare sector where staff shortage is high (Mercay et al., 2016). If individuals who train in the secondary segment do not receive information about further possible career steps or see appropriate advancement options, they might rather opt out of the profession altogether, as results concerning nurse turnover suggest (Hayes et al., 2012). Furthermore, this argument is supported by the fact that licensed healthcare assistants' mobility from the secondary to the primary segment is very low (see Section 2). Thus, career development through mobility into the primary segment seems to be limited and dropping out might be the most accessible option. An interesting avenue for further research would therefore be how training firm segments impact individuals' likelihood of leaving and re-entering the occupation or the labour market during their life course.

A major advantage of our study is that we can draw upon longitudinal data and use propensity score matching methods. This enables us to reduce the potential selection bias. By matching apprentices with training in the hospitals and those with training in nursing homes according to their SES, living area, and motivation, we can compare the outcome of similar individuals in the two segments. However, our findings are limited by the fact that we can neither fully control for individuals' intellectual abilities nor the differences in apprenticeship recruitment strategies of hospitals and nursing homes. Furthermore, our results are limited to the healthcare field. Future research could benefit from applying our theoretical framework to a wider set of occupations where individuals train in a primary or a secondary field.

\section{Acknowledgments}

The funding of this project has been supported by the Swiss State Secretariat for Education, Research, and
Innovation and OdASanté, who also provided organizational support in the field.

\section{Conflict of Interests}

The authors declare no conflict of interests.

\section{References}

Averitt, R. T. (1968). The dual economy. The dynamics of American industry structure. New York, NY: Norton.

Baron, J. N., \& Bielby, W. T. (1984). The organization of work in a segmented economy. American Sociological Review, 49(4), 454-473.

Becker, R., \& Hecken, A. E. (2007). Studium oder Berufsausbildung? Eine empirische Überprüfung der Modelle zur Erklärung von Bildungsentscheidungen von Esser sowie von Breen und Goldthorpe [University or vocational training? An empirical test of the rational choice model of educational choices suggested by Esser as well as Breen and Goldthorpe]. Zeitschrift für Soziologie, 36(2), 100-117.

Boudon, R. (1974). Education, opportunity and social inequality. Changing prospects in Western society. New York, NY: Wiley.

Buchmann, M., Kriesi, I., Koomen, M., Imdorf, C., \& Basler, A. (2016). Differentiation in secondary education and inequality in educational opportunities: The case of Switzerland. In H.-P. Blossfeld, S. Buchholz, J. Skopek, \& M. Triventi (Eds.), Models of secondary education and social inequality: An international comparison (pp. 111-128). Cheltenham: Edward Elgar Publishing.

Buchmann, M., Sacchi, S., \& Kriesi, I. (2002). Qualifications, dynamics of skill demand, and career outcomes. In F. Horváth (Ed.), Forum Bildung und Beschäftigung. Workshop Dokumentation [Education and employment forum. Workshop documentation] (pp. 229-241). Bern: Universität Bern.

Camenzind, P., \& Sturny, I. (2013). Kosten und Inanspruchnahme in der obligatorischen Krankenpflegeversicherung (OKP) der Schweiz. Analyse kantonaler Unterschiede und mögliche Erklärungsfaktoren [Costs and use of compulsory health insurance (OKP) in Switzerland. Analysis of cantonal differences and possible explanatory factors]. Neuchâtel: Schweizerisches Gesundheitsobservatorium.

Denzler, S. (2011). University or polytechnic? Family background effects on the choice of higher education institution. Schweizerische Zeitschrift für Soziologie, 37(1), 79-97.

Doeringer, P. B., \& Piore, M. J. (1971). Internal labour markets and manpower analysis. Lexington, MA: Heath and Company.

Dolder, P., \& Grünig, A. (2016). Nationaler Versorgungsbericht für die Gesundheitsberufe 2016. Nachwuchsbedarf und Massnahmen zur Personalsicherung auf nationaler Ebene [National health care report for 
the health professions 2016. Staff needs and measures to secure personnel at national level]. Bern: Schweizerische Konferenz der kantonalen Gesundheitsdirektorinnen und -direktoren (GDK) and $\mathrm{Na}$ tionale Dachorganisation der Arbeitswelt Gesundheit (OdASanté).

DuGoff, E. H., Schuler, M., \& Stuart, E. A. (2014). Generalizing observational study results: Applying propensity score methods to complex surveys. Health Services Research, 49(1), 284-303.

Dustmann, C. (2004). Parental background, secondary school track choice, and wages. Oxford Economic Papers, 56(2), 209-230.

Eggenberger, C., Rinawi, M., \& Backes-Gellner, U. (2018). Occupational specificity: A new measurement based on training curricula and its effect on labor market outcomes. Labour Economics, 51, 97-107.

Esser, H. (1991). Rational choice. Berliner Journal für Soziologie, 1(2), 231-243.

European Center for the Development of Vocational Training. (2012). Permeable education and training systems: Reducing barriers and increasing opportunity (Briefing Note). Thessaloniki: European Center for the Development of Vocational Training.

Forster, A. G., \& Bol, T. (2018). Vocational education and employment over the life course using a new measure of occupational specificity. Social Science Research, 70, 176-197.

Goebel, V., \& Kohler, F. (2014). Areas with urban character 2012: Explanatory report. Neuchâtel: Swiss Federal Statistical Office.

Gomensoro, A., Meyer, T., Hupka-Brunner, S., Jann, B., Müller, B., Oesch, D., . . . Scharenberg, K. (2017). Employment situation at age thirty: Results update of the Swiss panel survey TREE. Bern: TREE.

Griga, D., Hadjar, A., \& Becker, R. (2013). Bildungsungleichheiten beim Hochschulzugang nach Geschlecht und Migrationshintergrund. Befunde aus der Schweiz und aus Frankreich [Educational inequalities in access to higher education by gender and migrant background. Findings from Switzerland and France]. In A. Hadjar \& S. Hupka-Brunner (Eds.), Geschlecht, Migrationshintergrund und Bildungserfolg [Gender, migration background and educational attainment] (pp. 270-293). Weinheim: Beltz Juventa.

Hayes, L. J., O’Brien-Pallas, L., Duffield, C., Shamian, J., Buchan, J., Hughes, F., . . . North, N. (2012). Nurse turnover: A literature review-An update. International Journal of Nursing Studies, 49(7), 887-905.

Helbling, L. A., \& Sacchi, S. (2014). Scarring effects of early unemployment among young workers with vocational credentials in Switzerland. Empirical Research in Vocational Education and Training, 6(1), 12.

Hupka-Brunner, S., \& Kriesi, I. (2013). Ausbildungsbedingungen und Ausbildungszufriedenheit in der dualen Grundbildung: Die Rolle von Geschlecht und Migrationshintergrund [Training conditions and training satisfaction in upper secondary dual vocational edu- cation and training: The role of gender and migration background]. In A. Hadjar \& S. Hupka-Brunner (Eds.), Geschlecht, Migrationshintergrund und Bildungserfolg [Gender, migration background and educational attainment] (pp. 242-269). Weinheim: Beltz Juventa.

Hupka-Brunner, S., Sacchi, S., \& Stalder, B. E. (2010). Social origin and access to upper secondary education in Switzerland: A comparison of companybased apprenticeship and exclusively school-based programmes. Schweizerische Zeitschrift für Soziologie, 36(1), 11-31.

Jacoby, S. M. (1990). The new institutionalism: What can it learn from the OLD? Industrial Relations: A Journal of Economy and Society, 29(2), 316-340.

Jonker, N., van Ophem, H., \& Hartog, J. (2006). Dual track or academic route for auditors: Does it matter? Applied Economics, 38(9), 1019-1035.

Jung, J.-M. (2019). Lohnbuch Schweiz 2019 [Wage book Switzerland]. Zürich: orell füssli.

Kalleberg, A. L. (2003). Flexible firms and labor market segmentation: Effects of workplace restructuring on jobs and workers. Work and Occupations, 30(2), 154-175.

Kankaanranta, T., \& Rissanen, P. (2008). Nurses' intentions to leave nursing in Finland. The European Journal of Health Economics, 9(4), 333-342.

Kriesi, I., \& Trede, I. (2018). La formation professionnelle supérieure en Suisse: structure, état de la recherche et dimensions d'inégalité sociale [Higher vocational training in Switzerland: structure, state of research and dimensions of social inequality]. In J.-L. Berger, N. Lamamra \& L. Bonoli (Eds.), Enjeux de la formation professionnelle suisse. Le 'modèle' suisse sous la loupe [Challenges of Swiss vocational and professional education and training. The Swiss "model" under the microscope] (pp. 225-251). Zurich: Seismo.

Kristen, C. (1999). Bildungsentscheidungen und Bildungsungleichheit. Ein Überblick über den Forschungsstand [Educational choices and educational inequality. An overview of the state of research] (Working Paper no 5). Mannheim: Mannheimer Zentrum für Europäische Sozialforschung.

Lavrijsen, J., \& Nicaise, I. (2017). Returns on vocational education over the life cycle: Between immediate labour market preparation and lifelong employability. International Review of Education, 63(2), 257-280.

Lutz, B., \& Sengenberger, W. (1974). Arbeitsmarktstrukturen und öffentliche Arbeitsmarktpolitik [Labour market structures and public labour market policy]. Göttingen: Schwartz.

Mächler, K. (2014). Ein Karrieremodell für die Pflege in der Schweiz [A career model for nursing in Switzerland]. In R. Tewes \& A. Stockinger (Eds.), Personalentwicklung in Pflege- und Gesundheitseinrichtungen: Erfolgreiche Konzepte und Praxisbeispiele aus dem In-und Ausland [Personnel development in nursing and health care facilities: Successful concepts and practical examples from Switzerland and abroad] (pp. 
191-203). Berlin: Springer.

Menze, L. (2017). Horizontale und vertikale Adäquanz im Anschluss an die betriebliche Ausbildung in Deutschland [Horizontal and vertical matches after apprenticeship training in Germany]. KZfSS Kölner Zeitschrift für Soziologie und Sozialpsychologie, 69(1), 79-107.

Mercay, C., Burla, L., \& Widmer, M. (2016). Gesundheitspersonal in der Schweiz. Bestandesaufnahme und Prognosen bis 2030 [Health personnel in Switzerland. Review and forecasts until 2030]. Neuchâtel: Schweizerisches Gesundheitsobservatorium.

Morgan, S. L., \& Harding, D. J. (2006). Matching estimators of causal effects: Prospects and pitfalls in theory and practice. Sociological Methods \& Research, 35(1), 3-60.

Müller, B., \& Schweri, J. (2009). Berufswechsel beim Übergang von der Lehre in den Arbeitsmarkt. [Occupational change at the transition from apprenticeship to work]. Schweizerische Zeitschrift für Bildungswissenschaften, 31(2), 199-227.

Oertle Bürki, C. (2008). Fachhochschulen Gesundheit in der Schweiz: Konzeption und Aufbau im Umfeld der allgemeinen Fachhochschulentwicklung [Healthcare at the Universities of Applied Sciences in Switzerland: Conception and development in the context of the general development of universities of applied sciences]. Bern: Lang.

Piore, M. J. (2000). The dual labour market: Theory and implications. In D. B. Grusky (Ed.), Social stratification: Class, race, and gender in sociological perspective (2nd ed., pp. 550-553). Boulder, CO: Westview Press.

Preisendörfer, P. (1987). Organisationale Determinanten beruflicher Karrieremuster: Theorieansätze, Methodische Zugangswege und Empirische Befunde [Organizational determinants of occupational career patterns: Theoretical approaches, methodological approaches and empirical findings]. Soziale Welt, 38(2), 211-226.

Protsch, P., \& Solga, H. (2016). The social stratification of the German VET system. Journal of Education and Work, 29(6), 637-661.

Sacchi, S., Kriesi, I., \& Buchmann, M. (2016). Occupational mobility chains and the role of job opportunities for upward, lateral and downward mobility in Switzerland. Research in Social Stratification and Mobility, 44, 10-21.

Sacchi, S., \& Meyer, T. (2016). Übergangslösungen beim Eintritt in die Schweizer Berufsbildung: Brückenschlag oder Sackgasse? [VET entry in Switzerland via "bridging solutions": Stepping stone or dead end?]. Schweizerische Zeitschrift für Soziologie, 42(1), 9-39.

Salvisberg, A., \& Sacchi, S. (2014). Labour market prospects of Swiss career entrants after completion of vocational education and training. European Societies, 16(2), 255-274.

Schmid, E., \& Gonon, P. (2016). Transition from upper secondary VET to tertiary level education. In K.
Scharenberg, S. Hupka-Brunner, T. Meyer, \& M. M. Bergman (Eds.), Transitions in youth and young adulthood: Results from the Swiss TREE panel study (Vol. 2, pp. 208-230). Neuchatel: Seismo.

Schweri, J., \& Hartog, J. (2017). Do wage expectations predict college enrollment? Evidence from healthcare. Journal of Economic Behavior \& Organization, 141, 135-150.

Sengenberger, W. (1975). Arbeitsmarktstruktur. Ansätze zu einem Modell des segmentierten Arbeitsmarktes [Structure of the labour market. Approaches to a segmented labour market model]. Frankfurt a.M.: Campus.

State Secretariate for Education Research and Innovation. (2016). Vocational and professional education and training in Switzerland. Facts and figures 2016. Bern: State Secretariate for Education, Research and Innovation.

Swiss Federal Statistical Office. (2011). Abschlüsse der höheren Berufsbildung: eine statistische Bestandesaufnahme [Higher vocational education and training qualifications: A statistical review]. Neuchâtel: Swiss Federal Statistical Office.

Tolbert, C., Horan, P. M., \& Beck, E. M. (1980). The structure of economic segmentation: A dual economy approach. American Journal of Sociology, 85, 1095-1117.

Trede, I. (2015). Laufbahnentscheidungen von Fachfrauen und Fachmännern Gesundheit nach Abschluss ihrer beruflichen Grundbildung [Career decisions of healthcare assistants after their vocational education] (Unpublished Doctoral dissertation). Universität Bremen, Bremen.

Trede, I., Grønning, M., Pregaldini, D., Kriesi, I., Schweri, J., \& Baumler, C. (2017). Trained healthcare assistants: A dreamjob or a stopover? new results regarding the professional careers and educational pathways of vocational education and training graduates. Zollikofen: Swiss Federal Institute for Voational Education and Training and Nationale Dachorganisation der Arbeitswelt Gesundheit.

Trede, I., \& Kriesi, I. (2016). Übergang in die höhere Berufsbildung im Gesundheitsbereich: Die Rolle von Geschlecht und Migrationshintergrund [Transition into professional education in the healthcare field: The role of gender and migration background ]. In I. Horwath, I. Kriesi, B. Liebig \& B. Riegraf (Eds.), Gender und Migration in der tertiären Hochschulbildung [Gender and migration in tertiary higher education] (pp. 102-122). Münster: Westfälisches Dampfboot.

Trede, I., \& Schweri, J. (2014). Work values and intention to become a registered nurse among healthcare assistants. Nurse Education Today, 34(6), 948-953.

Vogtenhuber, S. (2014). The impact of within country heterogeneity in vocational specificity on initial job matches and job status. Journal of Vocational Behavior, 85(3), 374-384.

Wettstein, E., Schmid, E., \& Gonon, P. (2017). Swiss 
vocational and professional education and training (VPET). Forms, system, stakeholders. Bern: hep Verlag.
Wooldridge, J. M. (2010). Econometric analysis of cross section and panel data (2nd ed.). Cambridge, MA: MIT Press.

\section{About the Authors}

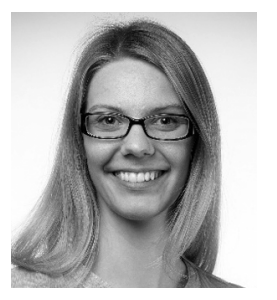

Miriam Grønning is a PhD candidate at the Leibniz University Hannover, Germany, and a Research Collaborator at the Swiss Federal Institute for Vocational Education and Training. In 2015, she completed the Research Master in Sociology at the University of Mannheim, Germany. Her research focuses on school-to-work-transitions, early labour market outcomes and institutional dimensions of education and training in the context of segmented labour markets.

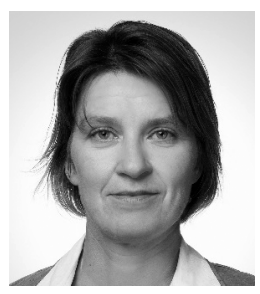

Ines Trede is Head of the Observatory for Vocational Education and Training at the Swiss Federal Institute for Vocational Education and Training. She holds a PhD in Human and Health Sciences from the University of Bremen, Germany. Her research and practice experience concerns occupational careers, labour force and training needs, as well as further development of Switzerland's professional education sector. 